\title{
Potential use of personal protection online search during COVID-19 pandemic for predicting and monitoring public response
}

\author{
Michael Chandra ${ }^{1}$, Rizma Syakurah ${ }^{2}$ \\ ${ }^{1}$ Medical Faculty, Sriwijaya University, Indonesia \\ ${ }^{2}$ Public Health Faculty, Sriwijaya University, Indonesia
}

\section{Article Info}

Article history:

Received Jun 27, 2020

Revised Aug 28, 2020

Accepted Sep 13, 2020

\section{Keywords:}

COVID-19

Handwashing

Google Trends

Indonesia

Mask

Risk communication

\begin{abstract}
COVID-19 has become a global public health emergency in almost all over the world, including in Indonesia. Effective risk communication becomes an emergency response to increase awareness and determine appropriate interventions. The study aimed to assess the success of risk communication monitoring using Google Trends during the COVID-19 pandemic in Indonesia. Quantitative and qualitative research uses time-series data (31 December 2019-2 May 2020). The relative search volume (RSV) of keyword 'masker' (mask) and 'cuci tangan' (handwashing) from Google Trends (GT) and the number of COVID-19 daily cases were collected. Analyzed qualitatively. RSV search data and daily case comparisons were performed based on Pearson correlation analysis and time lag correlation with significance $<0.05$. The keyword 'masker' has four peaks and 'cuci tangan' has three peaks with fluctuations due to the increase in mask prices, government policies, news, and official WHO recommendations. Validation using time-lag correlation shows the significant results between RSV keywords related to personal protection and the number of COVID-19 cases. The highest correlation was achieved by the keyword 'masker' three days before the number of COVID-19 cases. Google Trends can potentially be used as a complement and support for early warning systems in the surveillance system and improve public health responses in Indonesia.
\end{abstract}

This is an open access article under the CC BY-SA license.

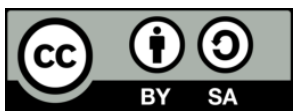

\section{Corresponding Author:}

Rizma Adlia Syakurah, Public Health Faculty, Sriwijaya University, Jl. Raya Palembang-Prabumulih KM. 32 Indralaya, Ogan Ilir, Sumatera Selatan, 30662, Indonesia. Email: rizma.syakurah@gmail.com

\section{INTRODUCTION}

World health organization (WHO) declared COVID-19 as a global pandemic on 11 March 2020, after previously reported an outbreak of lower respiratory tract disease in Wuhan, China, 31 December 2019 [1]. There were 3,588,773 confirmed cases and 247,503 deaths (case fatality rate 6.9\%) out of 214 infected countries (185 of which countries have experienced local transmissions) until 6 May 2020 [2]. Indonesia has become one of the countries with local transmissions with a total of 12,438 confirmed cases and 895 deaths (case fatality rate of $7.2 \%$ ) [3].

Risk communication is defined as the interchange of information, advice or opinions from experts to people who are currently at risk in the sector of health, economic or social [4]. Risk communication and community engagement (RCCE) is an evident manifestation of the application of risk communication that 
has been carried out in prior public health emergencies of international concern and has become an integral success in responding to emergency health problems [5]. Aspects of COVID-19 pandemic increases the risk perception in society as a result of the community's fear of COVID-19 such as high infection rates, significant disability and death rates, lack of protective measures or treatment and rapid increase of cases and, cases fatality rates [6]. These factors cause serious and unmeasured consequences as a result of increased risk perception. The most prominent example is the problem of personal protective equipment (PPE) limitations to protect doctors from the risk of infection. The limitation of PPE is caused by panic buying, stockpiling, and abuse which causes demand for PPE needs to increase [7, 8]. The consequence of this finding is the scarcity of PPE that should be provided to health workers who treat patients with suspected or confirmed COVID-19 which can ultimately lead to an increase in the number of illnesses and deaths of health workers during COVID-19 [8, 9].

The internet becomes more widely used as sources of health services information. Analysis of internet search habits is carried out through infodemiologists and infoveillance as a public health informatics method to increase situational awareness and appropriate interventions. Google Trends is an alternative facility for searching data on the level of public attention through relative search volumes (RSV). This data can be used for real-time analysis of the transmission, severity, and natural history of a disease pathogen, also predictions of an increase in infected cases [10].

Changes in conditions and information in the community develop rapidly during an unstable period. Transmission of up-to-date and reliable information must be a top priority for achieving appropriate and effective risk communication [8]. Therefore, researchers are interested in monitoring the response of the Indonesian people in finding data about COVID-19 during this pandemic using Google trends data that focuses on predicting and monitoring people's behaviour regarding personal protection, with the hope that the outcome of using Google trends as an early warning system and a tool for monitoring public reaction can be used to help risk communication during the COVID-19 pandemic in Indonesia.

\section{RESEARCH METHOD}

Quantitative and qualitative research used time-series data from 31 December 2019 to 2 May 2020. A new COVID-19 case report was obtained daily from the official website of the task force for the acceleration of COVID-19 handling in Indonesia by the national disaster mitigation agency (Badan Nasional Penanggulangan Bencana) (https://bnpb-inacovid19.hub.arcgis.com/). A Google trends (GT) search was conducted (https://trends.google.com/trends) with the keywords 'masker' (mask) and 'cuci tangan' (handwashing) at the same time. The keywords ought to represent information from the practice of personal prevention as a measure of handling COVID-19 disease transmission.

Every related spike found analyzed qualitatively as additional information. The relative search volumes (RSV) of each keyword are relative to time represented by the value 100 for the highest level and 0 for the lowest level. The RSV GT data was compared with the new daily cases data obtained from the official website of the task force for the acceleration of handling COVID-19 in Indonesia. Time-lagged correlation in the three-day interval of the number of COVID-19 daily new cases and GT data was used to assess between the correlation of the increase in GT data and the increase in COVID-19 cases, as has been done in previous studies $[11,12]$.

\section{RESULTS AND DISCUSSION}

Analysis of the data in Figure 1 shows the time series of COVID-19 cases in Indonesia from 31 December 2019 to 2 May 2020. The first case in Indonesia emerged on 2 March 2020 and has relatively increased to the present [3]. The time series of the COVID-19 case illustrated in a single graphical form along with Google Trends data. Based on the search terms from Google Trends, there were 4 peaks on the keyword 'masker' and 3 peaks on the keyword 'cuci tangan'. Figure 1 also shows search information using the keyword 'masker' having a higher value than the COVID-19 case report, while the keyword 'cuci tangan' tended to have a lower value. Both keywords also had queries that directly related to the keywords 'corona' and 'covid' as shown in Table 1. The results show that people were aware of the 'masker' and 'cuci tangan' associated with the COVID-19 incident.

The 'masker' keyword search trend in Indonesia was relatively balanced starting on 31 December 2020, when the first case of COVID-19 appeared in Wuhan, China. The search gradually increased on 25 January 2020 and reached its first peak on 6 February 2020, then experienced a gradual decline. The increased search for the keyword 'masker' in February 2020 was in line with the trend of an increase in mask exports up to 6.8 times higher than in January 2020 [13]. This high export resulted in a reduced circulation of masks in the community increasing demand for goods. Pharmacy in Blora, Central Java, 
stated that the stock of masks was empty because the supply from sales was no longer running [14]. As a result of the scarcity of mask products, the surge of face mask prices happened and the trend of increasing prices was spiking online with an average increase of 7-8 times [15]. The second peak occurred on 3 March 2020, one day after the first positive case of COVID-19 in Indonesia was confirmed, with an increase of more than 3.75 times compared to the previous day [16]. The discovery of this first case can trigger public panic which then flocked to look for a mask that intended as one of the tools to protect against coronavirus infections.

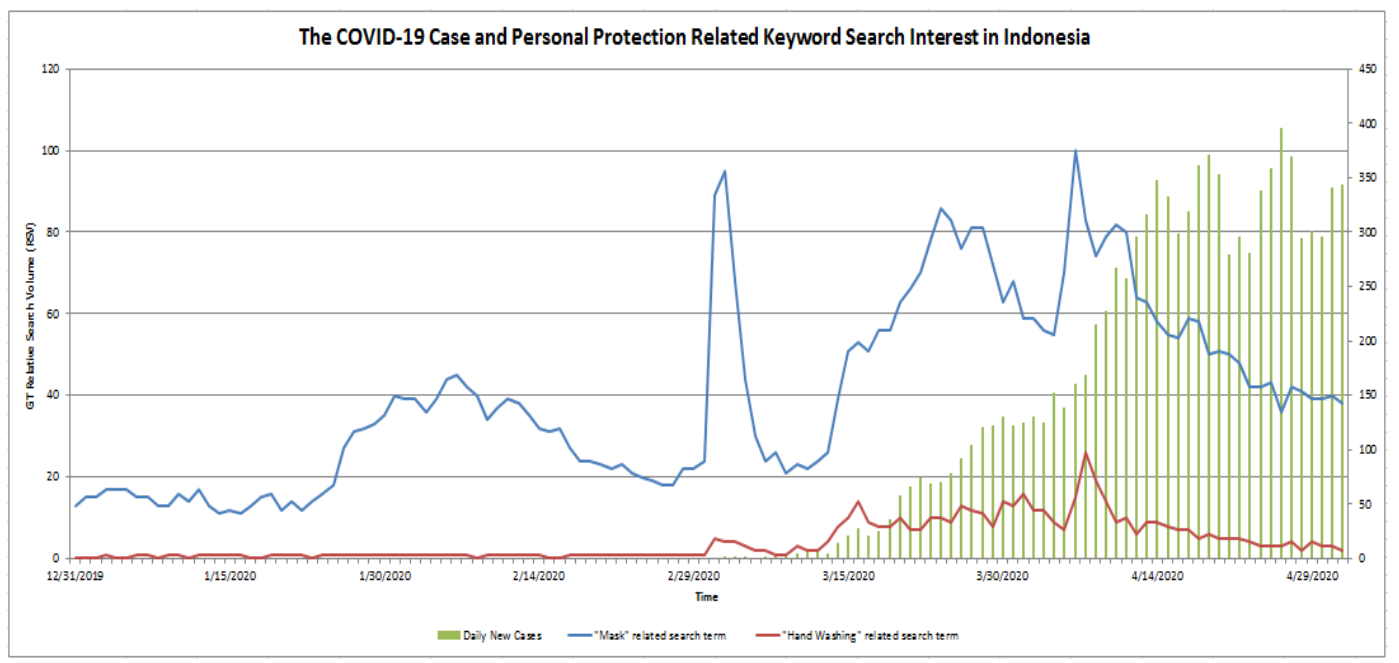

Figure 1. GT relative search volume (RSV) of COVID-19 case and personal protection related keyword search interest in indonesia for the period 31 December 2019-2 May 2020

Table 1. Queries of search interests with keywords related to personal protection

\begin{tabular}{|c|c|c|c|}
\hline \multicolumn{2}{|c|}{ 'Masker' } & \multicolumn{2}{|c|}{ 'Cuci tangan' } \\
\hline Bahasa & English & Bahasa & English \\
\hline 'Masker corona' & Corona Mask ' & 'Cuci tangan corona' & 'Wash hands corona' \\
\hline Scuba 'masker' & Scuba 'mask' & 'Cuci tangan COVID' & 'Wash hands COVID' \\
\hline 'Cara membuat masker kain' & 'How to make a fabric mask' & 'Gambar orang cuci tangan' & 'Pictures of people washing hands' \\
\hline 'Pabrik masker sensi' & 'Sensi mask factory' & 'Cuci tangan antiseptik' & 'Hand wash antiseptic' \\
\hline 'Distributor masker sensi' & 'Sensi mask distributor' & 'Gambar cuci tangan corona' & 'Hand washing corona image' \\
\hline 'Masker sritex' & 'Sritex mask' & 'Antiseptik' & 'Antiseptic' \\
\hline 'Sritex' & 'Sritex' & 'Gambar virus corona' & 'Corona virus image' \\
\hline 'Masker anti virus' & 'Anti virus mask' & 'Poster cuci tangan corona' & 'Corona hand washing poster' \\
\hline 'Pola masker kain' & 'Fabric mask pattern' & 'Poster cuci tangan COVID-19' & 'COVID-19 hand washing poster' \\
\hline 'Masker sensi murah' & 'Cheap sensi mask' & 'Cuci tangan png' & 'Wash hands png' \\
\hline
\end{tabular}

The subsequent increase in searches reached its peak on 16 March 2020, when the Government policies regarding online learning and working from home through the Ministry of Education and Culture and the statement of extending the COVID-19 disaster emergency status for 91 days until 29 May 2020 by the National disaster mitigation agency (BNPB) [17]. This upward trend continues until March 24. Several phenomena can explain this incident, including the statement of the Ministry of SOEs that has prepared PPE (masks) for distribution to the public, news of the arrest of traders who sold masks for Rp. 400,000 (normal price range of Rp. 50,000), as well as a statement from the Indonesian government spokesman for handling COVID-19 which claimed 80 percent of positive cases of corona in Indonesia had mild to moderate symptoms [18-20]. The statement of the Ministry of BUMN and the Indonesian government spokesperson for handling COVID-19 should reduce the anxiety in the community and prevent them from panic buying masks, while the news of securing traders who sold masks at high prices causes the interest of mask reseller traders to decrease, so the search figure for mask has decreased [18, 19].

The last peak was found on 6 April 2020, after previously increased starting on 4 April 2020 and decreased gradually thereafter. This increase coincided with the official statement from WHO regarding "Advice on the use of masks in the context of COVID-19". This statement contains a large amount of information in community and health care settings. Community settings also contain alternative 
suggestions beyond the use of masks in healthy people (because there was no sufficient evidence), for example through physical distancing, maintaining regular hand hygiene, good and proper cough ethics, and avoiding touching the face area especially the mouth, nose, and eyes [21].

The 'cuci tangan' keyword search in Indonesia has a relatively lower search volume compared to the 'masker' keyword. The first peak was observed to occur on 2 March 2020, related to COVID-19 first case findings and relatively stable thereafter [16]. The second peak occurred on 16 March 2020, with an increasing trend occurring since 13 March 2020, and relatively stable. Moreover, the Government policies regarding online learning and working from home through the Ministry of Education and Culture Circular and the statement of extending the COVID-19 disaster emergency status by BNPB, an increase in search trends may also due to the issuance of UNICEF's recommendation on "Everything you need to know about washing your hands to protect against coronavirus (COVID-19)" on the same day, resulting in an increase in public interest in searching various search term queries related to washing hands, for example, antiseptics, as shown in Table 1 [22]. The third peak occurred on 7 April 2020, caused by the recommended alternative protection from COVID-19 from WHO, which is one of them by maintaining hand hygiene regularly [21]. Afterwards, the search trend for the keyword "hand washing" tends to decrease until now.

Close contact and droplets have been proven from existing research as a method of spreading the virus that causes COVID-19. Therefore, the community can make prevention and mitigation efforts through the application of cough ethics, avoiding touching the mucous area of the face, following social distancing policies, doing regular hand hygiene, and wearing masks if they have respiratory symptoms [23]. Masks as part of PPE are experiencing global supply disruption. This is not only due to an increase in COVID-19 cases but also due to misinformation resulting in panic buying and stockpiling. This disruption will continue as long as PPE production is still limited and inappropriate use continues. Given that Indonesia often experiences a surge in the number of new cases and the prediction that Indonesia will reach 106,000 cases in July, public education will be urgently needed to prevent unnecessary use of masks [24, 25]. Educational considerations on the use of masks can be based on the intended use, risk of exposure, user vulnerability, life situation, sustainability, and type of mask used. WHO supports the use of masks during a COVID-19 pandemic, with the emphasis on the use of surgical masks aimed at health workers, while the public advised using masks made of cloth or homemade [21].

The Pearson correlation results in Table 2 show a low positive correlation (R-value .30 to .50 and $\mathrm{p} \leq 0.05)$ between the COVID-19 case report and Google Trends data. The correlation of the keyword 'masker' was higher than the keyword 'cuci tangan', with values of 0.4941 and 0.4612 , respectively. Time lag correlation results show a moderate positive correlation ( $\mathrm{R}$-value .50 to .70 and $\mathrm{p} \leq 0.05$ ) between COVID-19 case reports and Google Trends data 1-3 days before, with R-values in the range 0.5228-0.5720 for the keyword 'masker' and 0.5009-0.5696 for the keyword 'cuci tangan'. This finding was in accordance with research from Husnayain in 2020 which concluded a positive correlation between the GT search data and the positive case findings in Taiwan. The same study also concluded GT as a tool for monitoring public unrest due to the COVID-19 pandemic in Taiwan [11]. Previous studies have used Google Trends as a surveillance tool on various other diseases with strong correlation results [26-29]. The search for information using the keyword 'masker' three days before, showed the highest correlation with COVID-19 case reports, which showed the highest increase in search rates occurred three days before the increase in new cases of COVID-19.

Table 2. Time-lag Pearson correlations between 'Masker' keyword in GT RSV related to COVID-19 daily cases in Indonesia

\begin{tabular}{cccccccc}
\hline Keyword & \multicolumn{7}{c}{ Days } \\
\hline & -3 & -2 & -1 & 0 & 1 & 2 & 3 \\
"Masker" & $0.5720^{*}$ & $0.5394^{*}$ & $0.5228^{*}$ & $0.4941^{*}$ & $0.4681^{*}$ & $0.4486^{*}$ & $0.4325^{*}$ \\
"Cuci tangan" & $0.5696^{*}$ & $0.5493^{*}$ & $0.5009^{*}$ & $0.4612^{*}$ & $0.4360^{*}$ & $0.4148^{*}$ & $0.3820^{*}$ \\
\hline
\end{tabular}

* Pearson Correlation significant at $\mathrm{p} \leq 0.05$

Pearson's corr. Coef.

\begin{tabular}{|l|l|l|l|l}
\hline $0-0.2$ & $0.21-0.40$ & $0.40-0.60$ & $0.61-0.80$ & $0.80-1$
\end{tabular}

Figure 2 and Figure 3 show the distribution of personal protection keyword search interest in Indonesia marked by blue color for 'masker' and red for 'cuci tangan', with the level of interest indicated by brighter color. Correlation of 'masker' keywords related to COVID-19 daily cases with time-lag ranges 1-3 days before or without by Province in Indonesia showed significant results in 10 Provinces with the highest keyword 'masker' search rate based on Google Trends as shown in Figure 2 with a total of 15 provinces with significant value. Another note can be obtained was all Provinces in Java had 
a significant correlation. Similar results also obtained from the 'cuci tangan' keyword as shown in Figure 3 , although the level of significance experienced by fewer Provinces (10 Provinces), with 5 out of 6 Provinces on Java being significant (except the Special Region of Yogyakarta).

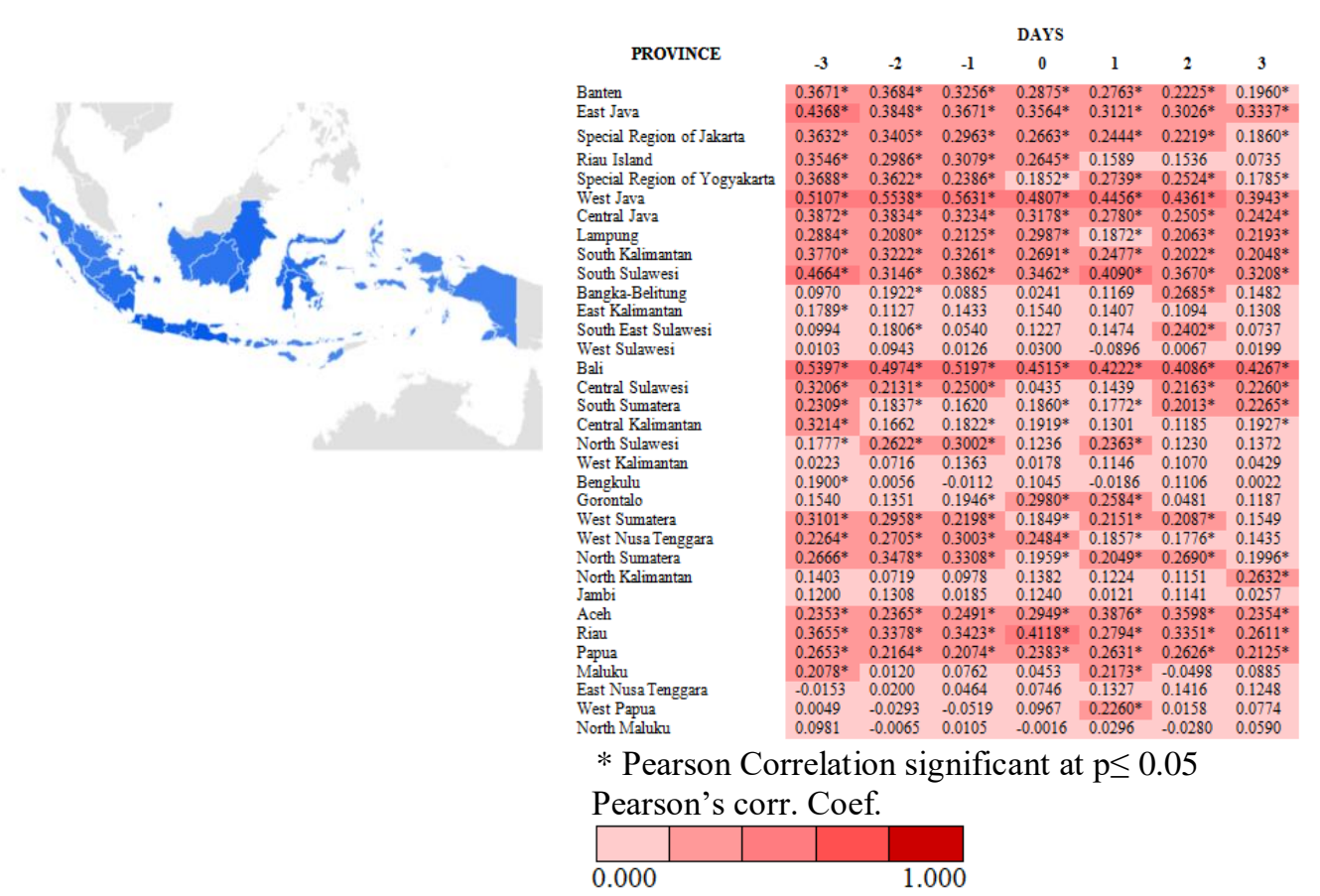

Figure 2. Time-lag correlations between 'Masker' keyword in GT RSV related to COVID-19 daily cases sorted from Province in Indonesia and the highest interest based on Google Trends
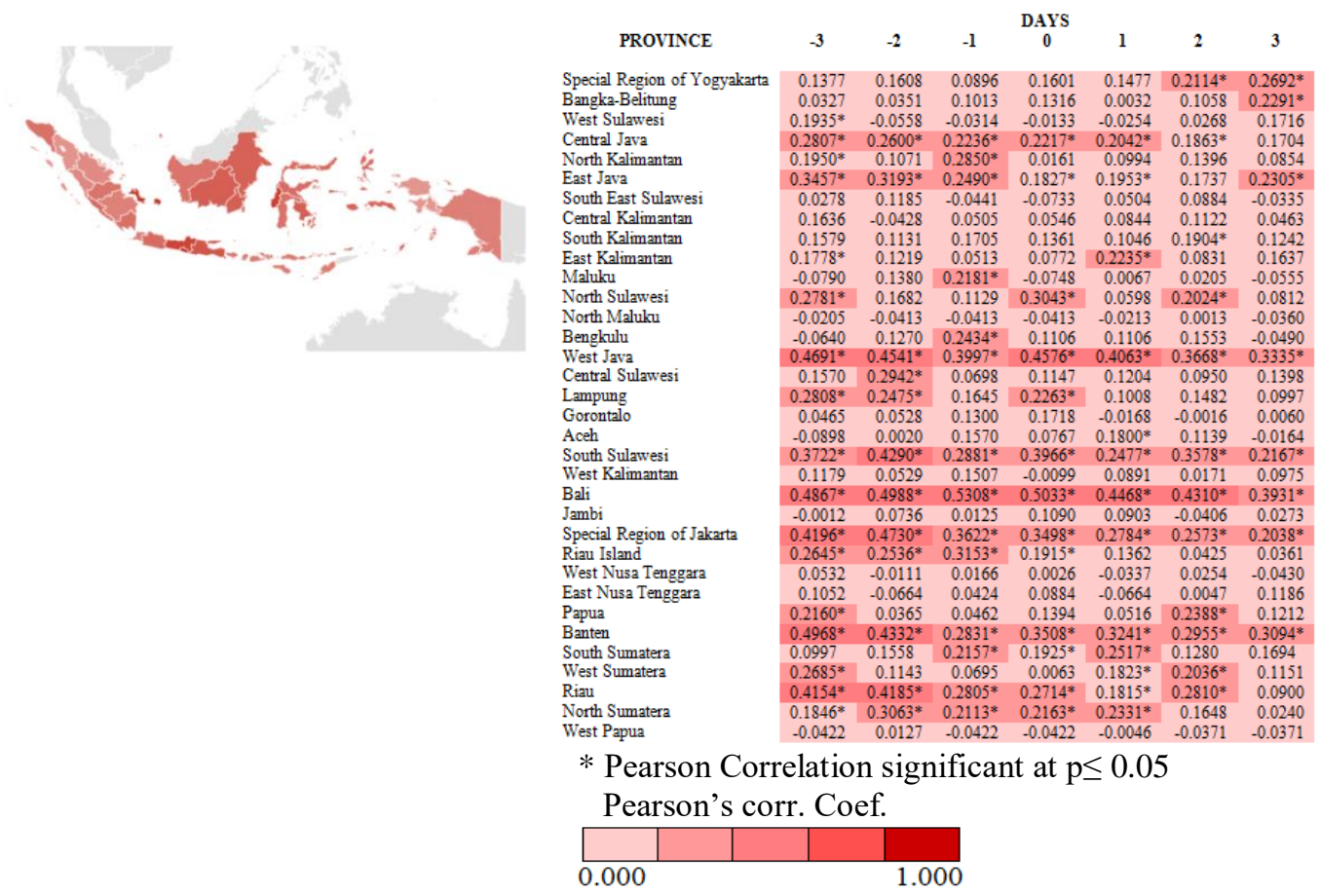

Figure 3. Time-lag correlations between 'cuci tangan' keyword in GT RSV related to COVID-19 daily cases sorted from Province in Indonesia and the highest interest based on Google Trends 
One of the efforts to prevent the Indonesian people is to access information about COVID-19 infection [30]. Information seeking behavior is a factor influencing internet search tendencies. This factor is influenced by various things, from internal factors such as age, gender, cultural aspects, language, social class, education level, marital status, and level of healthcare use and stress level, which may vary from one and another, and external factor such as internet penetration [11]. Another factor that influenced the recommended keywords on google search described based on previous search queries. Based on the description of search queries about the keywords 'masker' and 'cuci tangan', in general, the search of Indonesian people has led to the search for information related to 'corona' or 'covid'. This finding shows that the information-seeking behavior of Indonesian people has sharpened to the level of COVID-19 prevention through searching for protection methods of virus infections, although differs from conventional surveillance systems because it did not specifically describe the characteristics of individual searchers. Increased search for keywords related to personal protection 1-3 days before the increase in cases shows the potential use of Google Trends data as a complement and support for early warning systems in surveillance systems and has the potential to improve public health response in Indonesia [12].

In 2018, internet users in Indonesia reached over 150 million with $56 \%$ penetration spread throughout the region, while the number of mobile internet users was 142.8 million people with a penetration percentage of $53 \%$. The survey results of the Indonesian internet service providers association (Asosiasi Penyelenggara Jasa Internet Indonesia/APJII) in 2018 that internet users still had the highest percentage in Java (95.3 million people with $55.7 \%$ penetration) and Sumatra (36.9 million people with a penetration rate of $21.6 \%$ ) [31].

The number of internet users in various locations can determine the volume of internet searches. In general, there was a higher correlation in the region with higher internet penetration rates [11]. Other studies also show challenges related to internet penetration and information-seeking behavior in the implementation of Google Trends research in Indonesia [29]. Other research stated that Google Trends was more suitable for use in developing countries with wider internet penetration [24]. The application of the use of Google Trends in regions with low internet penetration is still a challenge and validation is needed to use Google Trends in regions with high disease prevalence in Indonesia with internet penetration levels as a comparison.

Each country has its conditions that can affect the successful implementation of COVID-19 transmission handling efforts that cause the method varied [32]. Some strategies proven to be able to reduce COVID-19 transmission rates were the implementation of physical distancing at specific locations, mass inspection efforts, cessation of PPE exports, and through strict infection control measures [33-35]. In Indonesia, physical distancing measures have been carried out through large-scale social restrictions propaganda (PSBB) to stop transmission of COVID-19, but in its implementation, the PSBB has not taken place effectively with the number of new cases continues to grow [36, 37]. Also, Indonesia is still one of the countries with the lowest COVID-19 examination rate in the world [37]. Researchers advise the government to take steps to deal with COVID-19 through efforts to increase the effectiveness of PSBB by establishing aggressive legal procedures for offenders and increase the number of tests based on population size.

\section{CONCLUSION}

Based on these findings, GT has the potential to be a tool for monitoring personal protection efforts in the community as a result of the COVID-19 pandemic in Indonesia in 1-3 days before the increase in the number of cases, as well as determine the appropriate location and time for risk communication which allows medical providers to make a tailored preventive and promotive measure. Analysis of personal protection efforts in the community when an outbreak occurs can increase risk communication from the government so that the public knows, wants, and can carry out early protection activities, so it is expected that the daily incidence rate of COVID-19 can be reduced. More efforts are needed to socialize hand hygiene to the public in the hope that the level of community knowledge in COVID-19 prevention will be better. The author suggests reaffirming the rules of PSBB and increasing the number of tests as an effort the government can carry out in tackling COVID-19 in Indonesia. The government of Indonesia can be used the GT as a tool for monitoring personal protection efforts and risk communication in the community.

\section{REFERENCES}

[1] World Health Organization. Coronavirus disease (COVID-19) situation report - 51. Geneva, CH: World Health Organization; 2020. [Online]. Available: https://www.who.int/docs/default-source/coronaviruse/situationreports/20200311-sitrep-51-covid-19.pdf?sfvrsn=1ba62e57_10 
[2] World Health Organization. Coronavirus disease (COVID-19) situation report-107. Geneva, CH: World Health Organization 2020. [Online]. Available: https://www.who.int/docs/default-source/coronaviruse/situationreports/20200506covid-19-sitrep-107.pdf?sfvrsn=159c3dc_2

[3] Kementerian Kesehatan Republik Indonesia, Current Situation of Coronavirus Disease (COVID-19) 7 May 2020 (Situasi Terkini Perkembangan Coronavirus Disease (COVID-19) 7 Mei 2020). [Online]. Available: https://covid19.kemkes.go.id/situasi-infeksi-emerging/info-corona-virus/situasi-terkini-perkembangan-coronavirusdisease-covid-19-7-mei-2020/\#.Xru2ADngqUk

[4] World Health Organization. General information on risk communication. [Online]. Available: https://www.who.int/risk-communication/background/en/

[5] World Health Organization. Risk communication and community engagement readiness and response to coronavirus disease (COVID-19): interim guidance, 19 March 2020. [Online]. Available: https://apps.who.int/iris/handle/10665/331513

[6] Smith, RD., "Responding to global infectious disease outbreaks: lessons from SARS on the role of risk perception, communication and management," Soc sci med, vol. 63, no. 12, pp. 3113-3123, 2006.

[7] World Health Organization. Shortage of personal protective equipment endangering health workers worldwide, 2020. [Online]. Available: https://www.who.int/news-room/detail/03-03-2020-shortage-of-personal-protectiveequipment-endangering-health-workers-worldwide

[8] Abrams, EM., Greenhawt, M., "Risk Communication During COVID-19," The Journal of Allergy and Clinical Immunology, vol. 8, no. 6, pp. 1791-1794, 2020.

[9] Lancet. The., "COVID-19: protecting health-care workers," Lancet (London, England), vol. 395, no. 10228, p. 922, 2020. doi: 10.1016/S0140-6736(20)30644-9

[10] Effenberger, M., Kronbichler, A., Shin, JI., Mayer, G., Tilg, H., Perco, P., “Association of the COVID-19 pandemic with Internet Search Volumes: A Google Trends TM Analysis," International Journal of Infectious Diseases, vol. 95, pp. 192-197, 2020. doi: https://doi.org/10.1016/j.ijid.2020.04.033

[11] Husnayain A., Fuad A., Su, ECY., "Applications of google search trends for risk communication in infectious disease management: A case study of COVID-19 outbreak in Taiwan," International Journal of Infectious Diseases, vol. 95, pp. 221-223, 2020. doi:https://doi.org/10.1016/j.ijid.2020.03.021

[12] Mahfuza, N., Syakurah, R.A, Citra, R. "Analysis and potential use of google trends as a monitoring tool for risk communication during covid-19 pandemic in Indonesia," Interational Journal of Public Health Science (IJPHS), vol.9, no.4, 2020. doi: http://doi.org/10.11591/ijphs.v9i4.20512

[13] Julita, L., "Deserved Rare! Domestic Masks On Exported, Chaotic, (Pantas Langka! Masker Dalam Negeri Pada Diekspor, Kacau), 2020. [Online]. Available: https://www.cnbcindonesia.com/news/20200318115558-4145754/pantas-langka-masker-dalam-negeri-pada-diekspor-kacau

[14] Adirin A., Examining the Causes of Scarcity of Masks in Blora (Menelisik Penyebab Kelangkaan Masker di Blora), 2020. [Online]. Avaiable: https://www.liputan6.com/regional/read/4196038/menelisik-penyebabkelangkaan-masker-di-blora

[15] Hasibuan L., Good news! Price for Masks \& Hand Sanitizers are down (Kabar Baik! Harga Masker \& Hand Sanitizer Turun nih) 2020. [Online]. Available: https://www.cnbcindonesia.com/lifestyle/20200501093719-33155672/kabar-baik-harga-masker-hand-sanitizer-turun-nih

[16] Yulisman L. Mother and daughter test positive for coronavirus in Indonesia, first confirmed cases in the country, 2020. [Online]. Available: https://www.straitstimes.com/asia/se-asia/indonesia-confirms-two-coronavirus-cases-president

[17] Koesmawardhani NW., Government Sets Corona Disaster Emergency Period until May 29, 2020 (Pemerintah Tetapkan Masa Darurat Bencana Corona hingga 29 Mei 2020). [Online]. Available: https://news.detik.com/berita/d-4942327/pemerintah-tetapkan-masa-darurat-bencana-corona-hingga-29-mei-2020

[18] Wahyudi, E., Ministry of BUMN: 4 Million Masks Ready for Distribution by End of March (Kementerian BUMN: 4 Juta Masker Siap Didistribusikan Akhir Maret), 2020. [Online]. Availablee: https://bisnis.tempo.co/read/1323366/kementerian-bumn-4-juta-masker-siap-didistribusikan-akhir maret/full\&view=ok

[19] Ruriansyah, E., Putra, K., Selling Rp. 400 thousand masks, traders secured by the police (Jual Masker Rp400 Ribu, Pedagang Diamankan Polisi), 2020. [Onlinee]. Available : https://www.vivanews.com/berita/metro/42010-jualmasker-rp400-ribu-pedagang-diamankan-polisi?medium=autonext

[20] Nugraheny, Erika D., Krisiandi, UPDATE March 24: 686 Positive Covid-19 Patients, 80 Percent Experience Mild Symptoms (UPDATE 24 Maret: 686 Pasien Positif Covid-19, 80 Persen Alami Gejala Ringan), 2020. [Online] Available: https://nasional.kompas.com/read/2020/03/25/06291011/update-24-maret-686-pasien-positif-covid-1980-persen-alami-gejala-ringan?page=all\#page4

[21] World Health Organization. Advice on the use of masks in the context of COVID-19: interim guidance, 6 April 2020. [Online]. Available: https://apps.who.int/iris/handle/10665/331693 (accessed on 11 May 2020).

[22] UNICEF. Everything you need to know about washing your hands to protect against coronavirus (COVID-19), 2020. [Online]. Available: https://www.unicef.org/coronavirus/everything-you-need-know-about-washing-yourhands-protect-against-coronavirus-covid-19

[23] World Health Organization. Rational use of personal protective equipment (PPE) for coronavirus disease (COVID19): interim guidance, 2020. [Online]. Available: https://apps.who.int/iris/handle/10665/331498

[24] Khafi, K., Indonesia reports highest daily rise in COVID-19 cases for the second time in a week, 2020. [Online]. Available: https://www.thejakartapost.com/news/2020/05/09/indonesia-reports-highest-daily-rise-in-covid-19cases-for-second-time-in-a-week.html 
[25] Afifa L., Muthiariny, DE., Indonesia Covid-19 Cases Predicted to Reach 106,000 in July: BIN, 2020. [Online]. Available online: https://en.tempo.co/read/1327292/indonesia-covid-19-cases-predicted-to-reach-106000-in-july-bin

[26] Pelat C., Turbelin C., Bar-Hen A., Flahault A., Valleron AJ., "More diseases tracked by using Google Trends," Emerging infectious diseases, vol. 15, no. 8, pp. 1327-1328, 2008. doi: 10.3201/eid1508.090299

[27] Carneiro H.A., Mylonakis E., "Google trends: a web-based tool for real-time surveillance of disease outbreaks. Clinical infectious diseases, vol. 49, no. 10, pp. 1557-1564, doi: 10.1086/630200

[28] Johnson AK., Mehta SD., "A comparison of Internet search trends and sexually transmitted infection rates using Google trends," Sexually transmitted diseases, vol. 41, no. 1, pp. 61-63. doi:10.1097/olq.0000000000000065

[29] Husnayain A., Fuad A., Lazuardi L., "Correlation between Google Trends on dengue fever and national surveillance report in Indonesia," Global health action, vol. 12, no. 1, p. 1552652, 2019. doi: 10.1080/16549716.2018.1552652

[30] Moudy, J., Syakurah, R., "Knowledge Related to Coronavirus Disease (COVID-19) Prevention Efforts in Indonesia (Pengetahuan Terkait Usaha Pencegahan Coronavirus Disease (COVID-19) di Indonesia), HIGEIA (Journal of Public Health Research and Development), vol. 4, no. 3, pp. 333-346, 2020. https://doi.org/10.15294/higeia.v4i3.37844

[31] Rizkinaswara L., Use of the Internet in Indonesia (Penggunaan Internet di Indonesia), 2019. [Online]. Available: https://aptika.kominfo.go.id/2019/08/penggunaan-internet-di-indonesia/

[32] World Health Organization. China shows COVID-19 responses must be tailored to the local context Geneva, CH: World Health Organization, 2020. [Online], Available: http://www.euro.who.int/en/health-topics/healthemergencies/coronavirus-covid-19/news/news/2020/4/china-shows-covid-19-responses-must-be-tailored-to-thelocal-context

[33] Prem K., Liu Y., Russell TW., Kucharski, AJ., Eggo RM., Davies, N., etc. "The effect of control strategies to reduce social mixing on outcomes of the COVID-19 epidemic in Wuhan, China: a modelling study," The Lancet Public Health, vol. 5, no. 5, pp. E261-270, 2020. doi: https://doi.org/10.1016/S2468-2667(20)30073-6

[34] Choudhury SR., "The world should look at South Korea as an 'exit strategy' to recover from pandemic, economist says., 2020. [Online]. Available: https://www.cnbc.com/2020/04/23/coronavirus-world-should-look-to-southkoreas-efforts-to-contain-outbreak.html (accessed on 16 May 2020).

[35] Her, M., "How is COVID-19 affecting South Korea? What is our current strategy?," Disaster Medicine and Public Health Preparedness, pp. 1-7, 2020. doi: 10.1017/dmp.2020.69

[36] Sutrisno Budi., Indonesia's strategy to end COVID-19 outbreak lacks effectiveness: Study, 2020. [Online]. Available: https://www.thejakartapost.com/news/2020/04/25/indonesias-strategy-to-end-covid-19-outbreak-lackseffectiveness-study.html

[37] Soeriaatmadja, Wahyudi. Indonesia ranks among world's worst in coronavirus testing rate, 2020. [Online]. Available: https://www.thejakartapost.com/news/2020/04/07/indonesia-ranks-among-worlds-worst-in-coronavirustesting-rate.html 